\title{
Thanatos in Shakespeare's Hamlet, Homer and Barker's Achilles, Barnes and Saunders: Warding off Death before Release into the Unknown
}

Shakespeare' in Hamlet, Homer ve Barker'in Achilles'den, Barnes ve Saunders'e: Ölümden Kaçmak, Sonunda Bilinmeyen'e Yenik Düşmek

\author{
Gillian M.E. Alban \\ Istanbul Kültür University, Turkey
}

\begin{abstract}
This paper offers an existential approach to writers' responses to death, evaluating their different views regarding our ultimate destiny, Thanatos. It considers the deliberations of Shakespeare's Hamlet, the archetypal death-ponderer, and Homer's Achilles, approaching our own time through contemporaries like Julian Barnes, George Saunders and Pat Barker. These writings spanning hundreds of years demonstrate our desire to evade or control death, while anticipating ultimate judgment for behaviour in this life, before loosening our attachment to life in accepting our final fate. We watch Hamlet's concern for his father's ghost tortured in purgatory and his wish for revenge, as it became surpassed by Hamlet's interrogations concerning his own mortality, still obsessed by death, to which force he finally surrenders. While Achilles had initially embraced a gloriously heroic, youthful death, Homer subsequently shows him mourning the loss of his life in Hades; Pat Barker shows Achilles as reconciled to death, even while attached to life in considering his child's future. The contemporary George Saunders presents Lincoln's young son caught in a liminal bardo of the dead, who are trapped in attachment to their mortal state, while Willie is enabled to transition to his final state of possible judgment and closure. Julian Barnes' wish-fulfilment dream or desire of heaven offers this ideal as a debased, corporeal paradise, leaving his character longing for meaning, even while trapped in the limitations of his own personality. Visions and dreams from Homer and Shakespeare onwards offer cryptic clues regarding unknown future states. These literary reflections through disparate eras indicate the human aspiration to evade death and whatever lies beyond it, while often positing a final surrender to death, alongside a wish for it to make sense of life through karmic resolution.
\end{abstract}

Keywords: Death, bardo, purgatory, judgment, resolution, nothing

Öz

Bu makale, Achilles'den Shakespeare'in Hamlet'ine, çağdaş yazarlar Julian Barnes ve George Saunders'e kadar ölüm olgusuna yaklaşımları tartışmayı amaçlar. Araştırmanın konusu olan yazarların eserleri, kader ve bilinmeyene gidişi kabullenmeden önce nihai adaleti beklerken bile ölümden kaçınma veya onu kontrol etme arzusunu ortaya koyar. Hamlet'in babasının araftaki hayaline olan ilgisi, daha sonra kendi sorunları arasında unutulur; Achilles erken ve şaşalı bir ölümü kabul etmişken Hades'deki kaybolan yaşantısının yasını tutar. Barker ise onu, ölümü kabullenmesine karşın oğlunun geleceğini planlarken gösterir. Çağdaş Saunders, 
Lincoln'ın genç oğlunun arafın eșiğinde tutulurken sonsuz kaderi, yargılanma ve sona ulaşma için onun cesaretlendirilmesini konu eder. Barnes'ın arzularını tatmin edecek cennet rüyası, aslında böyle bir cennetin bile nihai olarak kötü olduğunu gösterir, yarattığı karakter bir anlam aramakta ve kendi kişiliğinin tuzağına düşmektedir. İncelenen eserler göstermiștir ki, kaleme alındıkları dönemler farklı da olsa ölümden neye mal olursa olsun kaçınmaya çalışır ama sonuçta onu kabullenir ve mümkünse hayata nihai adaleti getirmesini umarlar.

Anahtar Kelimeler: Ölüm, araf, yargllanma, mahșer, çözüm, hiçlik

One Moment in Annihilation's Waste, One Moment, of the Well of Life to taste-

The Stars are setting and the Caravan Starts for the Dawn of Nothing-Oh, make haste! Oh Thou, who didst with Pitfall and with Gin

Beset the Road I was to wander in,

Thou wilt not with Predestination round

Enmesh me, and impute my Fall to Sin?

The Rubaiyat of Omar Khayyam, trans. Edward Fitzgerald

"Death was a man-a skeleton-with a scythe and a cloak coming for us, whereas it's written into our DNA. We carry death within us"

Julian Barnes interview with Kenneth Whyte

What do we know of the relationship between this world and any possible life beyond the grave, effectively the relation between our somatic body and our spirit or soul? Very little, or rather, we know that our body will decay after death, becoming food for worms, its elements dispersing to their organic parts, whatever memorial rites are employed as we surrender to physical corruption, or speedy dispersal through cremation, leaving any spectral survival highly debatable. Such issues remain ever-present in Hamlet, which effectively offers an objective correlative of death, ghosts and mourning. ${ }^{1}$ The Shakespeare who speaks to us through a thousand personalities wrote this play some years after the sudden death of his young son Hamnet, offering a detached, cerebrally haunting interrogation of the meaning of life in the face of death. It is King John from the same years that offers a moving cameo of a mother inconsolably grieving for her son Arthur, refusing accusations of madness in expressing her desperate longing and mourning for him, asserting that her sanity causes her to suffer his loss all the more sharply (King John 3.4.44-60). In Albert Camus' La Peste, witnessing a child's agonising death from the plague, Rieux contends: "je refuserai jusqu'à la mort d'aimer cette création où des enfants sont torturés" (Camus 174), as he refuses to countenance any order that tolerates the agonising death of children. Surely Shakespeare brought his "negative

\footnotetext{
$1 \mathrm{~T}$. S. Eliot found this play lacking any clearly embodied objective correlative (100), while its protagonist eternally springs to our mind with skull in hand, the play's discussion obsessively revolving around ghosts, death, mortality and mourning, amounting to an elusively fascinating objective correlative.
} 
capability"2 to bear on death in Hamlet, even as we cannot specify his location in this play which is replete with his ubiquitous presence. He steps behind the scenes to show us death the last enemy, and our tenacious hold on this life in fear of what may lie beyond it. Present existence is preferable to any dubious perpetuation beyond the grave, whether idyllic, conscious existence, or a painful accounting for our behaviour in this life.

This paper journeys through literary approaches to Thanatos, seen through the eyes of writers and characters who interrogate or narrate death and the grave, from Homer's Achilles, to Shakespeare's Hamlet, to the nineteenth century Lincoln and on into our era. These writers' responses to death illuminate our expectations regarding any future life, and our wish for resolution or judgment as a palliative attempt to make sense of this mortal coil. An existential, ontological approach of Jean-Paul Sartre might indicate that, however little difference it will ultimately make, a life freely and consciously led is preferable to one lived in insincerity and bad faith; integrity and authenticity are essential to free humans as moral agents, who themselves are "the unique source of value and the nothingness by which the world exists" (Sartre 627); there is nothing beyond the free integrity of mortal individuals. A discussion of life approaching death appears particularly apposite now, in the era of our present plague or pandemic, Covid 19, since death, which always accompanies us, now asserts an ever-present threat to us. On this side of the grave we struggle with our problems, while on the other side awaits the great unknown.

\section{Attitudes to Death, from Hamlet back to Achilles}

The deliberations of Hamlet have become a universal reference regarding death, its protagonist astutely remarking:

For who would bear the whips and scorns of time,

The oppressor's wrong, the proud man's contumely,

The pangs of déspised love, the law's delay,

The insolence of office, and the spurns

That patient merit of the unworthy takes,...

But that the dread of something after death-

The undiscovered country from whose bourn

No traveller returns-puzzles the will,

And makes us rather bear those ills we have

Than fly to others that we know not of? (Hamlet 3.1.70-82)

We cling to our flesh and blood, in ignorance of what horrors may await us beyond death, since no traveller has returned from the grave to inform us about it, declares Hamlet, despite the tenets of the Christian faith nominally espoused by Shakespeare, based on the principle of one who returned from death. The New Testament 'testifies' to Jesus throwing off the grave cerements, as reported by Mary Magdalene, Jesus' disciples, and tens of thousands of

\footnotetext{
2 John Keats describes Shakespeare's "negative capability" in a letter to his brothers in 1817, showing the "uncertainties, mysteries, doubts" of this writer's ubiquitous sympathies (Houghton 62).
} 
subsequent martyrs, who risked death in their certainty of inheriting eternal life, trusting the precedent of Jesus' resurrection. Not all were convinced; doubting Thomas had to place his hands in the wounds of Jesus, and every sceptic since weighs their doubts against the chance of sentient life surviving death. After conversing with his father's ghost, Hamlet is convinced that his father is suffering in purgatory: "confined to fast in fires/Till the foul crimes done in [his] days of nature/Are burnt and purged away" (1.5.11-13), informing Horatio and the watch that "It is an honest ghost" (1.5.138).

In Shakespeare's dramas the dead return as ghosts, often to plague the conscience of the guilty, like Macbeth, Richard III, or Brutus in Julius Caesar, or to direct the actions of a grieving son, as Hamlet here, or to bless those fighting wicked tyrants, like Henry Richmond in Richard III. Hamlet avers that he will tenaciously follow his father's injunction to remember his father and avenge his wicked murder by "that incestuous, that adulterate beast" (1.5.42) who stole his life, crown and queen in one fell swoop, condemning Hamlet senior precipitately to the purgatorial "sulphurous fires and tormenting flames" (1.5.3), his abrupt death leaving him suffering for his unconfessed sins: "Cut off even in the blossoms of my sins,/Unhouseled, disappointed, unaneled" (1.5.7677), without benefit of the last host or priestly unction, as emphasised in Greenblatt's discussion in Hamlet in Purgatory. ${ }^{3}$ This play suggests a fascinating transition between father John Shakespeare and the Protestant playwright who "was probably brought up in a Roman Catholic household in a time of official suspicion and persecution of recusancy" (Greenblatt 249), and hence susceptible to being "haunted by the spirit of his father pleading for suffrages to relieve his soul from the pains of purgatory" (249), since his old religionist father was born under the ancient rites and intercessory prayers, before the Protestant prayer book of 1552 made such acts illegal.

Yet Hamlet is almost immediately asserting, against his initial belief in his father's ghost, that it is "the dread of something after death-/The undiscovered country from whose bourn/No traveller returns" (3.1.78-80), which makes humans irresolute, indecisive cowards. This contradicts his previous assertion that his father had returned from death precisely to inform his son of his fate and to ensure remembrance and revenge from him. The mental presence and imagined loss of the father who would die shortly after he completed this play, and who would surely have desired to be prayed for according to the old rites, is suggested in their interaction, yet the son speedily relegates his father's injunctions and memorial requests to neglect. Hamlet's father's murder is immediately followed by his mother's marital "baked meats" (1.2.179), then the "hugger-mugger" interring of Polonius killed behind the arras (4.5.80), and Ophelia's "maimed rites" after her doubtful death (5.1.199),

${ }^{3}$ Greenblatt suggests that Hamlet senior was a believer in Roman Catholic purgatory, evinced by his words "unhouseled, disappointed, unaneled" (1.5.77), together with his wish for remembrance from his son, also alluded to in Hamlet junior's purgatorial "Saint Patrick" (1.5.136); such beliefs and practices were outlawed as recusant in the reformed Protestant church, which may have been mentally closer to the younger Hamlet, as shown in his writer, William Shakespeare. 
all of which to Jacques Lacan indicate the play's inadequate mourning rituals for the departed dead (40-41). The dead remain in the memories of the living as those we love and have lost, which only gradually release their grasp on our mind, through time and the enactment and partial closure of funeral ceremonies.

Cavell asserts that "the work of mourning is the severing of investment, the detaching of one's interests, strand by strand, memory by memory, from their binding with an object that has passed, burying the dead" (Cavell 186). This play shows Hamlet losing his initial determination for revenge, neglecting his promise to his father and severing his connections with the dead as he falls into procrastinating indecisiveness. Hamlet's scepticism makes him insert a speech in The Mouse trap play to "catch the conscience of the king" (2.2.580), apparently because the memory of his father's ghost, who had initially convinced him of his own fratricidal murder, has faded into a dubious visitation: "The spirit that I have seen/May be the devil" (2.2.573-74). Then, even as Claudius' disturbed reaction to the play once again revives Hamlet's certainty to "take the ghost's word for a thousand pound" (3.2.270-71), upon passing Claudius in prayer minutes later, he lets slip an opportunity to make summary execution of him, basing this reluctance on belief that any prayer will send "this bloody, bawdy villain!/Remorseless, treacherous, lecherous, kindless villain!" (2.2.554-55) straight to heaven, his sins cleansed, simply because he has knelt in prayer for forgiveness. He may well confess his overly cerebral irresolution, proving him incapable of action:

Thus conscience does make cowards of us all,

And thus the native hue of resolution

Is sicklied o'er with the pale cast of thought;

And enterprises of great pitch and moment,

With this regard, their currents turn awry. (Hamlet 3.1.83-87)

First persuaded of the honesty of the ghost, and then negligent, Hamlet is again jubilantly convinced by his words, then later hesitant regarding them. However sure he may be of the integrity of his father's ghost after two visitations and Claudius' clearly displayed moral guilt, as demonstrated in the play-within-theplay and vocalised in his subsequent failed efforts to pray, Hamlet never plans any revenge, although each theatre of spectators is freshly convinced of his father's bloody fratricide. Increasingly indifferent to his father's assumed ongoing torture in purgatory, he fails to obey the loving father and husband who appears in his mother's closet to step between him and personal revenge against his wife.

Hamlet's indeterminacy regarding his father's ghost, and the bloody, unholy revenge he urges him towards, results instead in the deaths not only of Polonius and Ophelia, Rosencrantz and Guildenstern, but also culminates in that of Laertes, Gertrude, Claudius and Hamlet himself. We may well wonder about his uncertainty regarding his father's ghost, as we listen to his deliberations that relegate his father to forgetfulness. A graveyard brings Yorick to his mind, with Caesar and Alexander, but not his lost father. By the 
time Hamlet faces Laertes in a fencing duel, he has resigned himself to whatever fate may face him: "we defy augury. There's a special providence in the fall of a sparrow. If it be now, 'tis not to come; if it be not to come, it will be now; if it be not now, yet it will come. The readiness is all" (5.2.202-205). Deliberating and finally accepting his own death, he has become oblivious to his father's fate. In his last breath Hamlet urges Horatio to draw his breath in pain in order to "tell [his own] story" rather than that of his father's murder, leaving the court in the final scene entirely unaware of Claudius' several crimes, as Hamlet sends him to follow his mother, ignoring any possible postmortal confrontation with his murdered brother, as "old Hamlet has in effect been forgotten" (Greenblatt 227).

Bradley declares Hamlet to be a play enacted between the intimation of "the religious idea of a soul come from purgatory, at the end, conveyed through the similar idea of a soul carried by angels to its rest" (Bradley 141); a trajectory from a father's death to that of his son's. In her fictional Hamnet, Maggie O'Farrell switches the focus of this play to Shakespeare's son, imaginatively recreating an alternative reaction of Shakespeare to death. She reflects the powerful influence on the playwright of the death of his young son Hamnet, causing him to write a play in his name a few years after this loss. She shows Hamlet as presenting two people on the stage, the living young man and the ghost of his dead father, the part we know to have been acted by Shakespeare:

As the ghost talks, she sees that her husband, in writing this, is taking the role of the ghost, has changed places with his son. He has taken his son's death and made it his own: he has put himself in death's clutches, resurrecting the boy in his place. 'O horrible! O horrible! Most horrible!' murmurs her husband's ghoulish voice, recalling the agony of his death. He has ... done what any father would wish to do, to exchange his child's suffering for his own, to take his place, to offer himself up in his child's stead so that the boy might live. (O' Farrell 366)

Thus O'Farrell's novel suggests the effect of his son's death on the playwright, driving him to recreate on the stage what he had lost, using the only power he had, that of using charismatic words to bring to life the irrevocably lost child.

In "Hamlet before Its Time," Margreta de Grazia synthesises multiple approaches to Hamlet, whose protagonist appears in any context with "a young man with skull in hand stand[ing] iconlike for the self-reflexive, freestanding Hamlet" (de Grazia 367), showing this play as an ever-changing mirror of humanity, remaining at the vanguard of contemporary thought for four hundred years, particularly since the Romantic era. She exemplifies Jacques Derrida's use of Hamlet's interaction with his father's ghost, and this ghostly throwing time out of joint, to indicate our relationship with the spectre of Marx. "In avenging his father's murder, Hamlet performs the messianic delay called for now in expectation of a justice barely on the horizon ... the incommensurate justice of a future yet to come [which] demands hard calculation" (Specters of Marx, qtd. in de Grazia, 373). Derrida demonstrates deconstructionism through Hamlet's ghost, stating that "ghosts confound 'all 
the 'two's,' or binaries, on which metaphysics grounds itself. Neither alive nor dead, here nor there, material nor immaterial, they can be said to stand for what metaphysics has left behind, the unassimilable leftovers of an ontological system" (de Grazia 375). Declaring that "everything is in Shakespeare" (Royle 39), Derrida uses Shakespeare's text to illustrate the eternally in-between, neither dead nor alive, knowing nor ignorant, for ever interrogating the presence of death in our lives, as O'Farrell similarly shows Hamlet on the stage as both "the young man, alive, and the father, dead. He is both alive and dead" (de Gazia 366), in what Royle calls an indeterminate, revenant "ghost tense" (39).

What of the Greek warrior Achilles, who after the death of Patroclus, was haunted by his friend's ghost while dragging the dead Hector around Troy? Patroclus returns to reproach his friend and request burial, since without burial, he is unable to cross the river Lethe to Hades. Mourning the loss of their comradeship, he asks Achilles to bury their bones together. As Achilles reaches out his arms to Patroclus in longing for some comfort, the spirit of his friend vanishes underground, gibbering like smoke. In desolation at being unable to embrace his friend, Achilles asserts that: "Something of us does survive in Hades' halls, some spirit and image of a man, but only with a shadowy existence, since all night long the spirit of poor Patroclus has been standing at my side, weeping and wailing. It told me what to do and looked marvellously like him" (Homer, Iliad book 23, 398). Guthrie names this lack of substance in the ghost or wraith as phrenes, which he translates as heart, or even guts, continuing: "After death the soul drags on indeed a bare existence, but has nothing that could be called immortality, for its separation from the body dooms it to an existence which is the negation of all that, in the opinion of the survivors, makes life worth living" (Guthrie 279). Life after death was assumed by the Greeks to be a shadowy, wraith-like existence.

Achilles had elected a glorious heroic death in preference to survival into an uninspiring old age, sequestered at home. However, when Odysseus encounters him in the underworld, with the dead crowding around the trench, drawn to the smell of the blood of sacrificed sheep, moaning with regret for their truncated lives in shadowy Hades, Achilles declares, counter to his original wish to die young: "My lord Odysseus ... spare me your praise of Death. Put me on earth again, and I would rather be a serf in the house of some landless man, with little enough for himself to live on, than king of all these dead men that have done with life" (Homer, Odysseus book 11, 184). Odysseus' mother informs her son of how she had died grieving for him: "It was my heartache for you, my glorious Odysseus, and for your wise and gentle ways that brought my life and all its sweetness to an end" (176). Thrice Odysseus attempts to embrace his mother; thrice she slips through his arms as a shadowy ghost, leaving him harrowed with pain, as she explains the plight of the dead: "once the life-force has departed from our white bones, all is consumed by the fierce heat of the blazing fire, and the soul slips away like a dream and flutters on the air" (177). Finally Odysseus, in sheer panic and "sudden fear that dread Persephone might send up from Hades' Halls some 
ghastly monster like the Gorgon's head" (188), the terrible Medusa, to irreversibly detain him in Hades, he escapes, leaving the dead to their unearthly, shadowy existence.

The postmodern reading of Pat Barker's The Silence of the Girls on the Trojan War reveals Achilles' grieving and longing for his friend Patroclus after his death, while facing his own death unflinchingly: "His death's determined by the gods" (299). In his last days he returns to his beginnings, remembering his mother Thetis' reluctance for the mortal coil of marriage and a son: "the long mistake of mortal life erased at last" (301), while he instead memorialises "the richness of life he's about to lose" (299), cherishing memories of his father Peleus. Even his grief for Patroclus softens into imagining him "gone ahead of him into the next room" (301). Together with Briseis, the captive girl who had caused Achilles' wrath when seized from him by Agamemnon, thus prolonging the war, they both remember their old friend, with any relationship of their own "filtered through their shared love for Patroclus" (302), the Greek who was kind, particularly to the captive girls. For himself, Achilles seems resigned to not having a future, as if he has lived all his life now: "because there is no future ... an old man's acceptance of death" (302). Yet the sudden realisation that Briseis is pregnant confronts him with the fact that "there is a future, though not a future he can be part of, but still, one he has to reckon with" (302). This brings a change, causing Achilles to plan for his posthumous heir. He plays his lyre, then informs Alcimus of Briseis' pregnancy, stating that if he, Achilles, dies, an outcome he expects to occur soon: "I want you to take her to my father. I want the child to grow up in my father's house" (304), thus placing his child in the known environment where he had grown up. Having reached this decision regarding the future, he returns to the lyre lament he had so often played near Patroclus, whose ghost finally appears spectrally before him, as Achilles ends in a tangle of indeterminate, unfinished notes, abruptly aware that: "that's it, that's the end-it's been there all along, only he wasn't ready to see it" (306). Looking at Briseis he states: "That's it... Finished" (306); "suddenly he knows; nothing, nothing comes next, because that's it, that is the end" (305-6). The end for him is nothing, although he must first complete any unfinished business before death overtakes him.

Humans evade death, the last unknown, in our ignorance of what will happen after we cast off mortality. We need to settle our accounts, whether moral, emotional or practical. And we hold on to the evils of this life rather than risking death for whatever dubious alternative may follow, as Hamlet states:

To be or not to be-that is the question.

To die-to sleep-

No more; and by a sleep to say we end

The heart-ache and the thousand natural shocks

That flesh is heir to; 'tis a consummation

Devoutly to be wished. To die-to sleep-

To sleep! Perchance to dream. Ay, there's the rub;

For in that sleep of death what dreams may come 
When we have shuffled off this mortal coil, Must give us pause ...

But that the dread of something after death - (Hamlet 3.1.56-78)

What may we awaken to while supposedly resting in peace? Or what may visit us in the strange, unearthly slumber of death? That is surely a matter of concern: Julian Barnes calls it "The Dream".

\section{Contemporary Reflections on Life Beyond Death}

To the perennial concerns of Shakespeare and Homer, when lives were hardy and tough, frequently cut off early through war or childbirth, disease and poverty, Barnes in the tenth chapter of $A$ History of the World in 101/2 Chapters offers a perspective on life beyond the grave through his protagonist's dream of heaven, concluding his panoramic readings of religious and secular history. His narrator enjoys the perfect breakfast, proceeds to go shopping, plays extraordinary golf and other sports, observing that his "game has improved no end" (358), enjoys limitless sex, and meets as many celebrities as he can identify. He does whatever he wishes to do, in the most satisfying way, for hundreds of years, without hitches or glitches, and gradually becomes utterly bored and phased by the entire experience. His experience amounts to what Gregory Rubinson calls the truly "corporeal and sybaritic" heaven (Rubinson 176) of a shallow man; physical satisfaction. As this paradisal state persists in uneventful, satisfying monotony for millennia, the narrator's thorough enjoyment of these activities starts to pall, making him feel no less than damned by such tedious perpetuity. While growing up in a Christian community, I had found the words of prayer: "for ever and ever, amen" utterly terrifying as a child; the everlasting persistence of continuing without interruption or relief, extending and stretching over an abyss of nothingness, without ever coming to an end, actually traumatised me for years. Barnes' protagonist finds the constant gratification of his fleshly pleasures pales through interminable repetition. He comes to appreciate that everything is great, but that he is not; there is no escape from one's own personality: "You can't become someone else without stopping being who you are" (Barnes 372). In the end he decides that endless life after death, however enjoyable it may be to indulge all his desires, in its sameness and repetition, leaves him simply gagging with nausea. Somewhat my response to the academic I encountered in Louisville who complained how there were so many scientists working in America, only a small percentage of whom were working on attaining eternal life, evading the clutches of death; I regarded her desire for endless perpetuity as deluded and crazy.

Barnes' fiction frequently engages with death; The Sense of an Ending circles the issue of youthful suicide, as the young in crisis or even in deliberation turn their back on life in despair or disgust. Barnes' personal experience of the death of his wife aged sixty-two has no doubt increased his existent fascination with death. Barnes has declared his belief in the unwavering finality of death; he does not believe he will see his wife again. Instead, he conjures his wife's reaction to things, engaging in an entirely self-generated "ventriloquism" 
which he feels to be not without meaning, his wife Pat's voice in his head offering a necessary prop to his own identity. He reports that in those first days and weeks, he found himself "missing what it was in her that made me more myself" (Brockes 1). He finds a friend's letter after his wife's death apposite: "The thing is, nature is so exact, it hurts exactly as much as it is worth, so in a way one relishes the pain. If it didn't matter, it wouldn't matter" (1). This is the exactness that his character in A History of the World finally seeks; give me an explanation, an evaluation of what I have done, beyond the tangible satisfactions of the body. Let it make some sort of sense. Instead of which he is told, you're $\mathrm{OK}$, leaving him feeling cheated.

George Saunders' view on life after death, in his Booker prize winning novel of 2017, Lincoln in the Bardo, imagines an interim, limbo world, while indicating a karmic accounting beyond death. It focuses on Abraham Lincoln's eleven-yearold son Willie, cut off from life when a cold turned to typhoid fever as he persisted in riding a gifted pony in inclement weather. The deceased boy is brought to a borrowed crypt or bardo inhabited by shades, whose conversations shed a macabre perspective on their fortunes in this world and beyond. 'Bardo' is a Tibetan Buddhist liminal state between death and rebirth, a transitional mode where the dead may experience reality if they are spiritually capable, or may undergo terrifying impulses from their previous, earthly state, karmically created, before they enter a less desirous rebirth. This approximates to the Turkish "araf," where the dead await transition to another world and judgment, which appears to share aspects of the Catholic interim state of undergoing burning in purgatory as experienced by Hamlet's father, preceding his judgment; Odysseus' mother also refers to trial by fire, or burning.

The newly dead Willie awaiting his father Lincoln's promised return to the crypt witnesses the dead's strong compulsion back towards the physical world from which they have been cut off, their unfinished business leaving them attached to life. Roger Bevins' emanation as sensory organs indicates his insatiable longing for life: "so many extra eyes and noses and hands that his body all but vanished Eyes like grapes on a vine Hands feeling the eyes Noses smelling the hands Slashes on every one of the wrists" (Saunders 27). This last shows how his "perverse predilections" towards young men, especially Gilbert, who rejected him, had made him slash his wrists over a bowl, then immediately feeling regret. The deed is done and he is dead, yet he remains under the misconception that he might return to his former life. Willie also sees "The other man (the one hit by a beam) Quite naked Member swollen to the size of Could not take my eyes off It bounced as he Body like a dumpling ... Quite naked indeed Awful dent in the head" (28), emanating as grossly phallic. Hans Vollman appears in a state of truncated passion, having married an eighteen-year-old girl at the age of forty-six and allowing her time to respond to him, until, warming to his generosity, she wishes to consummate their marriage. This is precisely the day when he is hit on the head by a ceiling beam, which tears him from life in a state of dreadful frustration: "the full pleasures of the marriage bed; when behold Anna's naked form; when will she 
turn to you in that certain state, mouth hungry, cheeks flushed; when will her hair, loosened in a wanton gesture, fall at last around you" (98), leaving his bodily shell frozen in a state of permanent tumescence.

These two ghosts encourage Willie not to wait for his father, but to move on from this transitional state, which can now only offer him depravity, as they show him young Elise Traynor, sexually abused by the ghouls who use her to relieve their own boredom. Initiated from youthful innocence into depravity, she has come: "to know, in my mind, serten untoward kwarters where such things Dim rum swoggling plases off bakalleys Kome to love them- Crave them places. And feel such anger. I did not get any. Thing. Was gone too soon- To get Only forteen. Yrs of aje" (38-39); they inform Willie that his psyche will undergo a similar degeneration in the bardo. Willie's determination to leave is temporarily shattered by his father's return to the crypt, as Willie runs to and straight through him, like ghostly shades in Hades passing through the physical, as Lincoln sobs over his son's shell, oblivious of Willie's present form. When his father picks up the dead "worm," a frantic, sentient Willie darts back and forth in dreadful frustration, until he manages to insert himself into his own dead form, as illustrated in the Patrick Swayze film Ghosts (1990). Clasped in his father's embrace, he listens to his loving words reassuring him of what a joy he had been to him and assuring him that he will return, as the boy glimpses some of his father's experiences, like "How it is to have a beard" (61).

A veritable pilgrimage of ghouls gather around the boy to learn what it had felt like to be embraced, while also remaining trapped in their personal obsessions. Each is attacked on their weakest point, after a softening through visions of "the fruited trees, the sweet breeze, the endless food, the magical streams" (90), before their personal susceptibility sweeps this illusory paradise from them, overwhelming them instead with their private obsessions. Bevins' lover Gilbert comes winsomely to inform his friend that everything is alright, only then to disillusion him that he is "a wave that has crashed upon the shore" (93) and hopelessly dead. Vollman's vision of his young wife speedily transforms into his flimsily dressed grandmother, who asserts: "Never. That's finished now. You delude yourself, Kugel" (98). Such tantalising onslaughts determine many wraiths to depart the bardo, electing transition to their ultimate destination under such frustrations. Intent on saving Willie, Bevin and Vollman catch up with Lincoln lingering in the graveyard, imagining his son to be "in some bright place, free of suffering, resplendent in a new mode of being" (161), which they know is false and deluded. Particularly the young and innocent are doomed to become trapped by carapaces or ghostly branches solidifying around them, imprisoning them away from "light" or positive aspirations, and exposing them to the degradations of a "depraved orgiastic cohort" (185), who attack their victim when pinioned into inaction and hence vulnerable to their insatiable lust. They use their utter boredom as an excuse: "We had sat every branch on every tree. Had read and re-read every stone. Had walked down ... every walk, path, and weedy trail, had waded every brook; [...heard each other's stories] many thousands of times" (124). This compares to Barnes' 
account of boredom, even in positive activity, as a discouragement of everlasting tedium after death.

As Bevins and Vollman enter Lincoln's body, they share his mourning over the premature extinction of his son's life spark: "When he is to be left out here? Is a person to nod, dance, reason, walk, discuss? As before?" (156), imagining his child "either in joy or nothingness. (So why grieve? The worst of it, for him, is over.)" (157), then advising himself to: "Think of him, when [he does] as being in some bright place, free of suffering, resplendent in a new mode of being" (158), which is unfortunately false. These ghosts try to share the misery of Elise with him, sensing her suffering when "manifesting as an ancient convent, containing fifteen bitter quarrelling nuns, about to burn to the ground.... Suddenly the place (the girl) is ablaze: screams, shrieks, grunts, vows, renounced if only one might be saved. But none are saved, all are lost" (167). Then they focus on the crypt's lock in Lincoln's hand to encourage him to return to his son there, while other ghosts rush into Lincoln to "harness that mass power, to serve our purpose" (252), their brief "serendipitous mass co-habitation" with him offering them a regenerative, shared humanity (256). Gaining a sense of responsibility from him, they urge Willie's tormenters to leave him alone, at which these ghouls retort that their particular predilections were not their own fault; as Omar Khayyam states in the above epigraph: "Thou wilt not .../ Enmesh me, and impute my Fall to Sin?" continuing: "Shall He that made the Vessel in pure love/And Fancy, in an after Rage destroy!" Will we really be brought to account for what we have done through the qualities that we were born with?

The reverend, who had fearfully fled his own after-life judgment, joins them in determining to release the boy, now almost incapacitated under surrounding carapaces, trapped as ghoulish demons slip multiple hands into his pantspocket, pumping and gasping over him (186). As "the two were bundled tightly together within a rapidly solidifying new carapace" (274) around him, the reverend pinioned with the boy gains a final vision of the "dreadful diamond palace!" (275) which had "crashed shut" (192) on him, when the Christemissary became beast, "bloody-handed and long-fanged" (192), convincing him of the "terrible judgment ... with whips of fire" (193) still awaiting him. He nevertheless embraces his quietus and moves on to face an Osiris-like judgment which he had fled from, when his weighed heart emerged as disgusting. He knew this fate would catch up with him, even as he had been sworn to silence, like Hamlet senior, sworn to secrecy while trapped by his sins in purgatory: "forbid/To tell the secrets of my prison-house" (1.5.13-14). Not understanding his faults, the reverend declares he "did not kill, steal, abuse, deceive; was not an adulterer, always tried to be charitable and just; believed in God and endeavoured, at all times, to the best of his ability, to live according to His will. And yet was damned" (Saunders 193), he ponders and wonders. While Barnes' narrator in his insipidly splendid heaven aspires judgment, and feels thwarted by the lack of assessment of his life when told: "you're OK" (354). 
Enabled by the reverend's explosive departure, Willie breaks free of the carapaces, as the other two dash off to the church with him, where Lincoln is still meditating. Willie sits on his father's knee, in his father's embrace, as Lincoln ponders his son's situation, alongside his other pressing domestic and national duties. But when he utters the words: "Willie is dead" (294), this instigates a liberating certainty in the boy. He finally realizes that the shell in the box no longer has anything to do with him, shouting: "Dead! The lad shouted, almost joyfully... Father said... I am dead" (296-297), as he understands the irreversible nature of his present condition. This liminal bardo merely postpones an unspecified but final, inevitable state, and his father will not return, or even if he did, he would never be allowed back into the old life, so the boy grasps his authenticity in reposting: "Why stay?... We're done. Don't you see?" (298), disillusioning the others about clinging to false hopes of holding onto this liminal state. Many release themselves from the bardo at this point, submitting to their ultimate destiny. Willie briefly passes through future, never-to-be-lived experiences, rapidly being a young man, father and widower, as he leaves in a "matter-lightblooming phenomenon and its familiar, but always bone-chilling, firesound" (300) which each ghost makes in moving on to their final state, relinquishing their precarious grasp on this charnel ground with its tentative proximity to the old life. Saunders remains silent about any such destination, while hinting at judgment; will they face dissolution, nothingness, or rebirth, in a return or dispersal to the elements of the world?

Willie's departure releases Lincoln to his perpetuating sorrows and duties. Facing the suffering of the American Civil War, he deliberates to "lead the rabble in managing" (308) the necessary liberation of the black race, as some black folk immerse themselves in Lincoln, offering both sides a mutually illuminating bond. Bevins and Vollman also determine to move on, releasing themselves from their bondage trapped within this liminal state. They achieve the positive action of releasing Elise from her depravities through their own exit. "Though the things of this world were strong with [them] still" (334), they determine to relinquish them, instigating their explosion next to her, freeing her to move on also. This shadowy graveyard bardo, like Homer's Hades, leaves the dissatisfied dead longing for what they have left behind in their lives, even as Saunders proffers a last-ditch redemption or chance to create karmic meaning. Vollman and Bevins release Elise, while the reverend frees Willie even in facing his own judgment: "going into that unknown place content that he had, at any rate, while in this place, done all that he could" (276). Life without meaning is intolerable; how satisfying to manage a final post-death agency, leaving the world however slightly better. Saunders implies a Buddhist karma in his macabre wish-fulfilment projection of a grim future world. Better any meaning than to aspire the cliché Christian eternity of praising God in the clouds.

Barnes' postmodern perspective on paradise shows his protagonist in idyllic circumstances, while finally utterly bored by its repetition and lack of challenge. After he has enjoyed doing everything he wishes and more, he starts 
to question; he worries about his health, his cash, or who is running this place, and what sort of place it could be, where Hitler visibly goes about his business-after all, what happened to hell and punishment? Hell apparently exists as a spooky theme park, a place where it is others who are punished, not oneself, which scarcely fits any concept of a moral universe. "People prefer to get what they want rather than what they deserve" (365) and everything appears too anodyne. He starts to enquire about God, learning that religious people had desired the God experience, although most of them were dying out. This perfect Heaven offers whatever one wants in a benign, wish-fulfilling continuation of life. And in the end, when that becomes meaningless through its tedium, it turns out that one may choose termination the second time round, because, well, there just doesn't seem much point in continuing with a meaningless existence for ever. His mentor informs him: "People who want an eternity of sex, beer, drugs, fast cars-that sort of thing. They can't believe their good luck at first, and then, a few hundred years later, they can't believe their bad luck [because] that's the sort of people they are, they realize. They're stuck with being themselves. Millennia after millennia of being themselves. They tend to die off the soonest" (369), as their chosen world becomes irritatingly too good to be true (Buxton 81).

The ones who buck this trend are either Old Heaveners, who keep worshipping for aeons, or the scholars. It's reassuring to learn that the intellectuals get a kick out of perpetual life: "They like sitting around reading all the books there are. And then they love arguing about them. Some of those arguments ... go on for millennium after millennium. It just seems to keep them young, for some reason, arguing about books" (369). But ultimately even this New Jerusalem is too boringly perfect, a "hellish repetition of increasingly tiring perfection" (Buxton 82); in the end any exit may be preferable to a nightmare from which there appears no escape. At this point Buxton returns to Barnes' half chapter on love, suggesting that this offers something in our present life which is not contained in the heavenly hereafter. Buxton implies that this may be Barnes' closest approximation to solving our problems: "Love won't change the history of the world ... but it will do something much more important: teach us to stand up to history, to ignore its chin-out strut. I don't accept your terms, love says; sorry, you don't impress, and by the way what a silly uniform you're wearing" (Barnes 289-290).

Barnes reverts to the existential question of identity and personal integrity in evaluating life: "You can't become someone else without stopping being who you are. Nobody can bear that" (372). If one's own existence becomes tedious and without meaning, eventually death may appear preferable. His character determines that "Heaven's a very good idea, it's a perfect idea you could say, but not for us. Not given the way we are" (372) and "getting what you want all the time is very close to not getting what you want all the time" (373). Identity also implies the concept of reaping the consequences of your life, making us accountable. Both Barnes' and Saunders' novels indicate our need for life ultimately to attain some meaning; Barnes' character wishes for judgment and approval of his life, even as he acts as he pleases. In a post-death bardo, 
Saunders vindicates a handful of characters who achieve something moral after death, claiming a last-ditch grasp at meaning for their limited lives, before they relinquish their hold on existence, thus asserting their personality in the shadows. As for Barnes, he declares that his "argument [is] against the existence of a man-created God, an approvable God or a just God ... There is either a God and a plan and it's all comprehensible, or it's all hazard and chaos, with occasional small pieces of progress. Which is what I think" (Kate Saunders in Rubinson), as he regards dreams of heaven and justice after this life as "ultimately a kind of self-delusive wishful thinking" (Rubinson 177). Barker shows Achilles closer to such a view, in bravely facing death, resigned to accepting whatever may come, after sorting out his life, while Homer actually shows him in a severely diminished underworld. In Hamlet, a dead father's ghost shockingly opens the drama, the role associated with Shakespeare the actor, and ends with many deaths, its various discussions of death remaining the play's major legacy to us. The dialogue of Hamlet and the ghost fades, as Hamlet moves beyond his father's injunctions, sufferings and desire for absolution, prayers and revenge, becoming caught up instead in his own endless reflections on life and death, only eventually to relinquish control of his destiny in his own readiness for death.

These reflections on Thanatos, from classical and Elizabethan, to contemporary writers, I offer in the time of Covid 19. Initially clinging to this world and evading death, we remain fixated on our temporal concerns and fearful of death as our last invincible enemy. We aspire authenticity and we hope for significance and closure to life even in death, hoping to escape pain and punishment. We remain bound up with the recollections of our own dead, mourning them for a season, until they loosen their hold on those of us left behind, as we too will gradually finally release our grasp on this mortal world. In our desire for meaning, we aspire to retain our present sentient state, although that is the least likely probability of all these humanly created possibilities. Wishing for some control over our destiny, death will eventually wrench all from our determined grasp, as life fades away, in the words of James Joyce in "The Dead:" "His own identity was fading out into a grey impalpable world: the solid world itself, which these dead had one time reared and lived in, was dissolving and dwindling ... the descent of this last end, upon all the living and the dead" (Joyce 220).

\section{Works Cited}

Atwood, Margaret. Negotiating with the Dead: A Writer on Writing. Cambridge University Press, 2002.

Barber, Lynn. "Julian Barnes Dances Around Death," Nothing to be Frightened of by Julian Barnes. The Telegraph Review, 5.3. 2008.

Barker, Pat. The Silence of the Girls. Penguin Books, 2018.

Barnes, Julian. A History of the World in 101/2 Chapters. Picador, Pan Macmillan, 1989.

Bradley, A.C. Shakespearean Tragedy. St. Martin's Press, 1969. 
Brockes, Emma. "Interview with Julian Barnes: The Sense of Another Ending." The Guardian Review, 30.03.2013.

Buxton, Jackie. "Julian Barnes's Theses on History (in 101/2 Chapters)." Contemporary Literature, vol. 41. no 1 (Spring, 2000), pp. 56-86.

Camus, Albert. La Peste. Gallimard, 1947.

Cavell, Stanley. Disowning Knowledge in Seven Plays of Shakespeare. Cambridge University Press, 1987, 2003.

Derrida, Jacques. From Specters of Marx: What is Ideology, 1994.

De Grazia, Margreta. “Hamlet before its Time.” Modern Language Quarterly 62.4 (Dec. 2001), 355-375.

Eliot, T.S. The Sacred Wood: Essays on Poetry and Criticism. Methuen \& Co. Ltd. 1920.

Greenblatt, Stephen. Hamlet in Purgatory. Princeton University Press, 2001.

Guthrie, W.K.C. The Greeks and their Gods. Methuen \& Co. Ltd., 1950.

Homer. The Odyssey. Trans. E.V. Rieu. Penguin Books, 1946.

Homer. The Iliad. Trans. E.V. Rieu, revised Peter Jones with D.C.H. Rieu. Penguin Books, 2003.

Houghton, Lord. The Life \& Letters of John Keats. Dent \& Sons Ltd., 1969.

Joyce, James. Dubliners. Penguin Books, 1914, 1956.

Khayyam, Omar. The Rubaiyat. Trans. Edward Fitzgerald. Jarrold \& Sons, Ltd.

Lacan, Jacques, Jacques-Alain Miller and James Halbert. "Desire and the Interpretation of Desire in Hamlet." Yale French Studies: Literature and Psychoanalysis: The Question of Reading, 55.56 (1977), pp. 11-52.

O'Farrell, Maggie. Hamnet. Tinder Press, 2020.

Royle, Nicholas. Derrida's Event," Derrida's Legacies: Literature and Philosophy, ed Simon Glendinning and Robert Eaglestone. Routledge, 2008.

Rubinson, Gregory J. "History's Genres: Julian Barnes's A History of the World in 101/2 Chapters." Modern Language Studies, vol. 30, no 2 (Autumn 2000), pp. 159-179.

Sartre, Jean-Paul Being and Nothingness: An Essay on Phenomenological Ontology. Trans. Hazel E. Barnes. Methuen \& Co. Ltd., 1943, 1958.

Saunders, George. Lincoln in the Bardo. Bloomsbury, 2017.

Shakespeare, William. Hamlet. Longman, 1970.

Shakespeare, William. The Complete Works. Collins, 1951. 